\title{
Effectiveness of Food Fortification in Improving Nutritional Status of Mothers and Children in Indonesia
}

\author{
Nikmah Utami Dewi ${ }^{1, *(D)}$ and Trias Mahmudiono ${ }^{2, *(D)}$ \\ 1 Department of Nutrition, Faculty of Public Health, University of Tadulako, Palu 94148, Indonesia \\ 2 Department of Nutrition, Faculty of Public Health, University of Airlangga, Surabaya 60115, Indonesia \\ * Correspondence: nikmah@untad.ac.id (N.U.D.); trias-m@fkm.unair.ac.id (T.M.)
}

Citation: Dewi, N.U.; Mahmudiono,

T. Effectiveness of Food Fortification in Improving Nutritional Status of Mothers and Children in Indonesia. Int. J. Environ. Res. Public Health 2021, 18, 2133. https://doi.org/10.3390/ ijerph18042133

Academic Editor: Paul B. Tchounwou

Received: 12 January 2021

Accepted: 17 February 2021

Published: 22 February 2021

Publisher's Note: MDPI stays neutral with regard to jurisdictional claims in published maps and institutional affiliations.

Copyright: (c) 2021 by the authors. Licensee MDPI, Basel, Switzerland. This article is an open access article distributed under the terms and conditions of the Creative Commons Attribution (CC BY) license (https:// creativecommons.org/licenses/by/ $4.0 /)$.

\begin{abstract}
Food fortification programs have been conducted in several countries to overcome micronutrient deficiency and related problems with various degrees of effectiveness. Available information regarding the success of food fortification programs in some developing countries, including Indonesia, is still limited. Thus, this study conducts a systematic review of the effects of food fortification of mothers and children using biochemical and anthropometric measures focusing on linear growth. Three databases were used in the literature search, namely PubMed, Science Direct and Google Scholar. Fifteen articles were included for analysis from 517 studies found consisting of Indonesian and English articles published from 2000 to June 2020. Fortification of iron, vitamin A, and iodine can increase the level of hemoglobin, serum ferritin, and serum retinol and median urine iodine excretion, especially in toddlers and schoolchildren. However, multinutrient fortification interventions were associated with various effects on hemoglobin, serum ferritin, and serum retinol but a positive association was found with linear growth indicators in the form of body length for age. The effectiveness of food fortification in reducing the prevalence of stunting still needs more and stronger evidence through studies with large sample size and longer duration.
\end{abstract}

Keywords: fortification; Indonesia; nutritional status; stunting

\section{Introduction}

Hidden hunger is a form of micronutrient deficiency that is still experienced by various developing countries, including Indonesia [1]. In Indonesia, in 2018, the percentage of children with anemia was $38.5 \%$, which increased by $10.4 \%$ compared with that in $2013[2,3]$. The percentage of individuals with anemia among pregnant women was much higher, $37.1 \%$ in 2013 , and increased to $48.9 \%$ in 2018 [2,3]. The high prevalence of anemia in Indonesia is mostly related to low iron intake or infectious diseases that increase iron loss from the body, leading to iron deficiency [4-7]. Iron deficiency is a major cause of anemia $[2,3]$ and a risk factor for zinc deficiency that can result in stunting [8,9].

One of the biggest nutritional problems in Indonesia is stunting. Although the prevalence of stunting among children under 5 years old in Indonesia has decreased from $37.2 \%$ to $30.8 \%$ [2,3], the number of cases still raises a public health concern [10]. The serious implications of stunting experienced by children and its impact on Indonesia's development have made stunting reduction a national priority with a target of decreasing it to $19 \%$ by 2024 [11].

A program aiming to reduce community nutritional problems, including stunting, should be multisector and consistent with specific and sensitive programs [12]. Specific programs include short-term interventions for which results can be recorded in a relatively short time using activities performed by the health sector, whereas sensitive programs are long-term interventions in the form of activities that are mostly macro and performed across institutions [12]. Food fortification programs are an example of sensitive programs conducted in several countries [12]. Food fortification programs conducted worldwide included fortification of vitamin A in cooking oil, margarine, and sugar; vitamin D in milk 
and margarine; folic acid in flour; iodine in salt; iron in milk, corn flour, beans, pearl millet, and wheat flour [13-16]. In Indonesia, the most critical fortification interventions are iodine in salt and iron fortification of wheat flour, whereas the fortification of vitamin A in cooking oil was optional, but now compulsory since 2020 [17-19].

Food fortification in several countries is associated with different effects on nutritional status or the reduction of the prevalence of nutritional problems. Iron fortification in foodstuffs is associated with increased hemoglobin and serum ferritin levels and decreased the prevalence of anemia in children, pregnant women, adolescents, and adults $[16,20,21]$; however, it was not positively related to a decrease in stunting and malnutrition in children under 5 years old [22]. Fortification of vitamin A in oil, margarine, sugar, and processed foods increased serum retinol levels [23-25], whereas fortification of vitamin A in staple foods showed the opposite result [26]. Fortification of salt decreased the prevalence of goiter and cretinism and increased the median urinary excretion of iodine [27], whereas fortification of foods other than salt increased urinary excretion of iodine but not height growth based on child age [28].

We are focusing on the fortification of micronutrients, namely, vitamin A, iron, and iodine, in a single food or with other micronutrients. These micronutrients were the focus of fortification in Indonesia until 2020 to reduce the prevalence of vitamin A deficiency, anemia, disorders due to iodine deficiency (IDD), and stunting [29]. In Indonesia, several studies have been conducted to examine the correlation between food fortification and nutritional status [30-41]. However, a meta-analysis or systematic review has never been conducted. We systematically reviewed the literature from the past 20 years published in English and Bahasa Indonesia to determine the association between food fortification programs in Indonesia and improvement of nutritional status in mothers and children using biochemical and anthropometric measures related to stunting.

\section{Materials and Methods}

This was an unregistered systematic review aimed to assess the effects of food fortification of mothers and children using biochemical and anthropometric measures focusing on stunting. Literature was searched using the PubMed and ScienceDirect databases for English-language studies and Google search engine for Indonesian-language studies. The keywords used were "fortification," "Indonesia," "nutrition," "anemia," "vitamin A," "iron," "iodine," "malnourished," and "stunting." Articles used only in English and Indonesian. Using these keywords, we obtained 517 articles on PubMed search, 179 articles in ScienceDirect, and 339 articles in Google including Google Scholar. In addition, article searches were performed on the selected article bibliography to ensure that all relevant articles had been included in the review list.

Articles were assessed by title and abstract based on certain inclusion and exclusion criteria. The identification of titles and abstracts was performed to see the suitability of the data presented with the stated objectives. The results of food fortification studies using nutritional status as the dependent variable were included in the review. The fortification included were vitamin A, iron, and iodine, into a single food or with other micronutrients. Nutritional status included anthropometry consisting of weight, height/body length, weight for age, height/body length for age, birth weight, knee height, and biochemical measures consisting of hemoglobin, serum retinol, serum ferritin, urine iodine excretion, and hematocrit. The studies were published from 2000 to June 2020 involving study samples consisting of groups of children, women and pregnant women with their babies. The research designs of the studies reviewed consisted of cross-sectional, cohort, quasiexperimental, randomized controlled trial (RCT), and nonrandomized controlled trial (Non-RCT) designs. Articles not in English nor Indonesian and those that did not study anemia, vitamin A deficiency, and iodine deficiency were excluded from this review. The articles were also excluded if they did not contain nutritional status measurements. Articles with conference abstracts, not original studies and containing information similar to the 
other articles were also excluded (Figure 1). Home fortification involving the use of Sprinkle was not included in this review because it was not conducted on the same type of food.

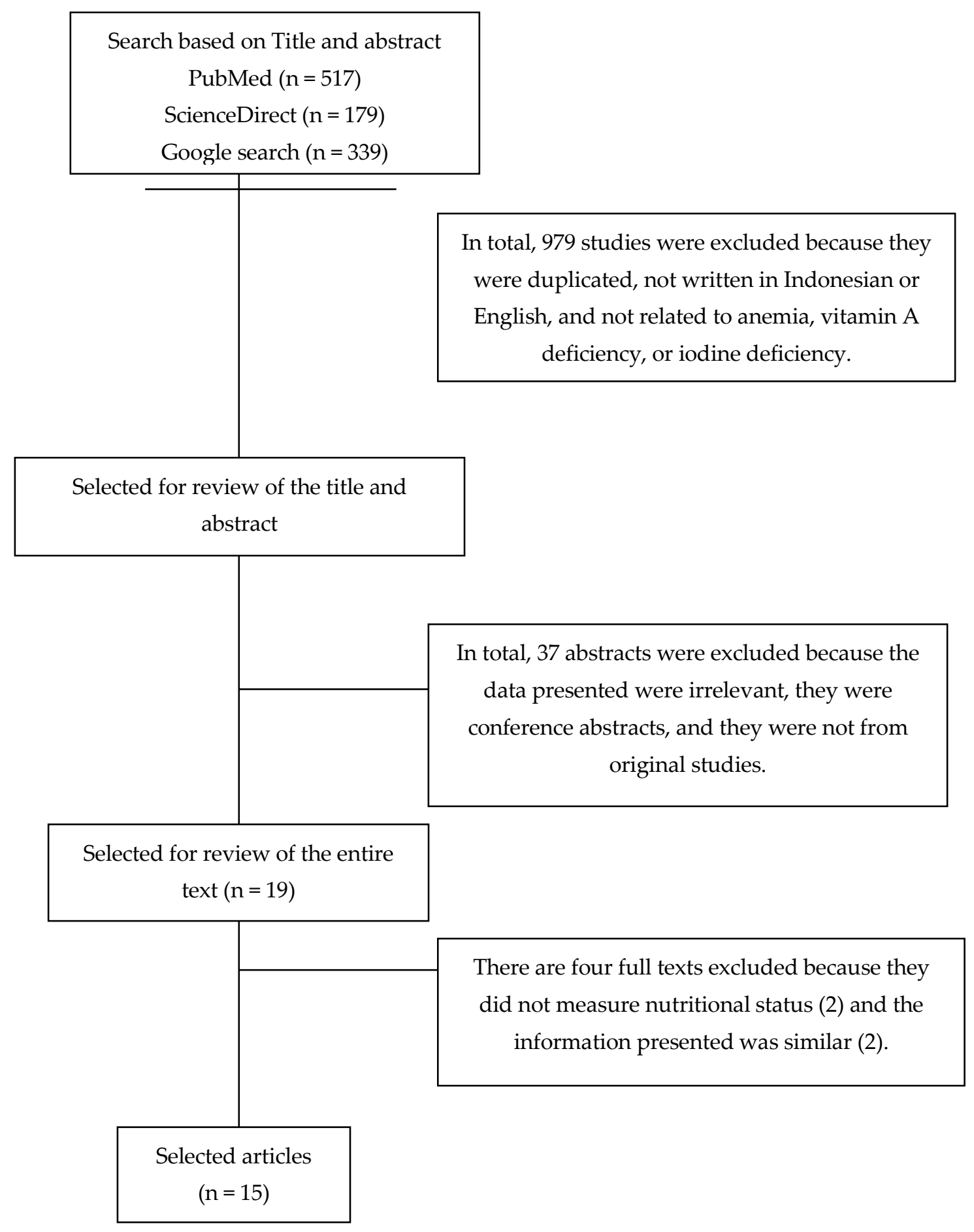

Figure 1. CONSORT diagram of the literature search and determination.

The articles that met the inclusion criteria were coded and are summarized in Table 1, including information on the study design, sample size, and participants, and Table 2, including duration, intervention, control provided, and the results obtained. In total, 15 articles were included according to the criteria used in this review. 
Table 1. Studies on the relationship between food fortification and nutritional status.

\begin{tabular}{|c|c|c|c|c|c|c|c|}
\hline No. & Reference & Year & Study Design & Sample Amount ( $n$ ) & Group & $\begin{array}{l}\text { Location } \\
\text { (Province) }\end{array}$ & $\begin{array}{l}\text { Duration } \\
\text { (Days) }\end{array}$ \\
\hline \multicolumn{8}{|l|}{ Iron } \\
\hline 1 & Sari [30] & 2001 & $R C T$ & 132 & \multirow{2}{*}{$\begin{array}{l}\text { 4-6 years old } \\
6 \text { months followed up to } \\
12 \text { months old }\end{array}$} & Jakarta & 21 \\
\hline 2. & Diana [31] & 2017 & Cohort & 190 & & West Java & 84 \\
\hline \multicolumn{8}{|l|}{ Vitamin A } \\
\hline 1. & Achadi [32] & 2010 & $\begin{array}{c}\text { Quasi- } \\
\text { experimental }\end{array}$ & 394 & 8-9 years old & South Sulawesi & 84 \\
\hline 2. & Sandjaja [33] & 2015 & $\begin{array}{c}\text { Quasi } \\
\text { experimental }\end{array}$ & $\begin{array}{c}\text { Breastfeeding mother: } \\
335,12-59 \text { months old: } \\
477,5-9 \text { years old: } 186, \\
\text { woman } 15-29 \text { years old: } \\
171\end{array}$ & $\begin{array}{c}\text { Breastfeeding mother, baby } \\
\text { aged 6- } 11 \text { months, children } \\
\text { aged } 12-59 \text { months, children } \\
\text { aged 5-9 years, women aged } \\
15-29 \text { years }\end{array}$ & West Java & 336 \\
\hline 3. & Sudikno [34] & 2017 & Cohort & 126 & $\begin{array}{l}\text { Children of poor family, } \\
6-59 \text { months old }\end{array}$ & West Java & 336 \\
\hline \multicolumn{8}{|l|}{ Iodine } \\
\hline 1. & Kasmawati [35] & 2015 & Non-RCT & 26 & $\begin{array}{l}\text { 10-12 years old with urinary } \\
\text { iodine excretion value of } \\
<100 \mu \mathrm{g} / \mathrm{L}\end{array}$ & South Sulawesi & 10 \\
\hline 2. & Samsudin [37] & 2015 & $\begin{array}{c}\text { Quasi- } \\
\text { experimental }\end{array}$ & 160 & $4-9$ years old & Central Java & 168 \\
\hline 3. & Samsudin [36] & 2016 & RCT & 176 & 6-12 years old & Central Java & 168 \\
\hline \multicolumn{8}{|l|}{ Multinutrient } \\
\hline 1. & Widayanti [38] & 2007 & $R C T$ & 70 & $\leq 5$ years old & West Java & 112 \\
\hline 2. & Prihananto [39] & 2007 & $R C T$ & 210 & Pregnant mothers & West Java & 168 \\
\hline 3. & Saragih [40] & 2007 & Cohort & 120 & $\begin{array}{l}\text { Pregnant mothers with } \\
\text { babies up to } 6 \text { months old }\end{array}$ & West Java & 336 \\
\hline 4. & Saragih [41] & 2012 & Cohort & 120 & $\begin{array}{l}\text { Pregnant mothers with } \\
\text { babies up to } 6 \text { months old }\end{array}$ & West Java & 336 \\
\hline 5. & Kurnia [43] & 2010 & $\begin{array}{c}\text { Quasi- } \\
\text { experimental }\end{array}$ & 91 & $\leq 5$ years old & Central Java & 84 \\
\hline 6. & Semba [44] & 2011 & Cross-sectional & 302,190 & 6-59 months old & $\begin{array}{c}\text { West Sumatera, } \\
\text { Lampung, Banten, } \\
\text { Jakarta, West Java, } \\
\text { Central Java, East } \\
\text { Java, West Nusa } \\
\text { Tenggara, South } \\
\text { Sulawesi }\end{array}$ & - \\
\hline 7. & Diana [31] & 2017 & Cohort & 190 & $\begin{array}{l}6 \text { months followed up to } \\
12 \text { months old }\end{array}$ & West Java & 84 \\
\hline 8. & Toruntju [42] & 2017 & $\mathrm{RCT}$ & 80 & $\begin{array}{l}\text { Boys, } 12-15 \text { years old, with } \\
\mathrm{Hb} \text { concentration of } \\
8-12 \mathrm{mg} \%\end{array}$ & West Java & 168 \\
\hline
\end{tabular}

Table 2. Type and level of fortification and food vehicle.

\begin{tabular}{|c|c|c|}
\hline Study & Type and Level of Fortification & Food Vehicle \\
\hline $\begin{array}{l}\text { Iron } \\
\text { Sari [30] } \\
\text { Diana [31] }\end{array}$ & $\begin{array}{l}\text { Iron } 30 \mathrm{mg} \text {, weekly dose } \\
\text { Iron }\end{array}$ & $\begin{array}{l}\text { Candies } \\
\text { Baby food }\end{array}$ \\
\hline $\begin{array}{l}\text { Vitamin A } \\
\text { Achadi [32] } \\
\text { Sandjaja [33] } \\
\text { Sudikno [34] }\end{array}$ & $\begin{array}{l}\text { Vitamin A: } 13.6 \mathrm{mg} \text { retinol } / \mathrm{kg} \\
\text { Vitamin A: } 13.6 \mathrm{mg} \text { retinol } / \mathrm{kg} \\
\text { Vitamin A: } 13.6 \mathrm{mg} \text { retinol } / \mathrm{kg}\end{array}$ & $\begin{array}{l}\text { Cooking oil } \\
\text { Cooking oil } \\
\text { Cooking oil }\end{array}$ \\
\hline $\begin{array}{l}\text { Iodine } \\
\text { Kasmawati [35] } \\
\text { Samsudin [37] } \\
\text { Samsudin [36] }\end{array}$ & $\begin{array}{l}\text { Iodine: } 0.4 \mathrm{mg} / \mathrm{kg} \mathrm{KIO} 3 \\
\text { Iodine: } \geq 30 \mathrm{mg} / \mathrm{kg} \mathrm{KIO} 3 \\
\text { Iodine: } 15-55 \mathrm{mg} / \mathrm{kg} \mathrm{KIO} 3\end{array}$ & $\begin{array}{l}\text { Eggs } \\
\text { Salt } \\
\text { Salt }\end{array}$ \\
\hline $\begin{array}{l}\text { Multinutrient } \\
\text { Widayanti [38] }\end{array}$ & $235.65 \mu \mathrm{g}$ of vitamin A and $4.17 \mathrm{mg}$ of iron $/ 100 \mathrm{~g}$ of biscuits. $76 \mathrm{~g}$ in a week & Biscuits \\
\hline $\begin{array}{l}\text { Prihananto [39], Saragih [40], } \\
\text { Saragih [41] }\end{array}$ & $\begin{array}{l}\text { - } \quad \text { Biscuit/100 g: iron: } 16 \mathrm{mg} \text {; iodine: } 36.76 \mathrm{mcg} \text {; zinc: } 6.3 \mathrm{mg} \text {; folic acid: } 66.72 \mathrm{mcg} \text {; } \\
\text { vitamin A: } 345.76 \text { RE; vitamin C: } 46.39 \mathrm{mg} \\
\text { Vermicelli/100 g: iron: } 4.4 \mathrm{mg} \text {; iodine: } 18.27 \mathrm{mcg} \text {; zinc: } 4.4 \mathrm{mg} \text {; folic acid: } \\
\text { 159.56 mcg; vitamin A: } 494.906 \text { RE; vitamin C: } 45,27 \mathrm{mg} \\
\text { Milk/100 g: iron: } 22.58 \mathrm{mg} \text {; iodine: } 58.40 \mathrm{mcg} \text {; zinc: } 3.29 \mathrm{mg} \text {; folic acid: } 48.55 \mathrm{mcg} \text {; } \\
\text { vitamin A: } 468.19 \text { RE; vitamin C: } 127.2 \mathrm{mg}\end{array}$ & Vermicelli, milk, biscuits \\
\hline Kurnia [43] & $\begin{array}{l}\text { Iron and zinc } 10 \mathrm{mg} / 100 \mathrm{~g} \text { biscuits. } 300 \mathrm{~g} \text { in a week } \\
\text { Vitamin } \mathrm{A} \text {, vitamin } \mathrm{C} \text {, vitamin } \mathrm{D} \text {, vitamin } \mathrm{E} \text {, vitamin } \mathrm{K} \text {, vitamin } \mathrm{B} 12 \text {, thiamine, and }\end{array}$ & Tempeh rice-bran biscuits \\
\hline Semba [44] & $\begin{array}{l}\text { riboflavin } \\
\text { Vitamin B6, niacin, folic acid, and iron. }\end{array}$ & Milk and instant noodles \\
\hline Diana [31] & Iron, zinc, calcium, vitamin A & Baby food \\
\hline Toruntju [42] & Iron, $\mathrm{Zn}$, vitamin B1, vitamin B3, folic acid, and vitamin B12 & Rice \\
\hline
\end{tabular}




\section{Results}

The 15 studies consisted of five RCTs [30,36,38,39,42], four quasi-experimental studies [32,33,37,43], four cohort studies [31,34,40,41], one cross-sectional study [44], and one non-RCT [35]. Most studies were conducted in the West Java region [31,34,38-42,44]. Three studies were conducted in Central Java [36,37,43], two studies in South Sulawesi [32,35], and one study in Jakarta City [30] and one used single samples from several cities in Indonesia [44] (Table 1).

Two studies assessed the effectiveness of iron fortification [30,31], three studies assessed the effectiveness of vitamin A fortification [32-34], three studies assessed iodine fortification [35-37], and eight studies assessed multinutrient fortification, including the effectiveness of iron fortification with the addition of other nutrients [31,38-44]. Fortified food ingredients included oil [32-34], candies [30], biscuits [38-41,43], vermicelli [39-41], instant noodles [44], milk [39-41,44], rice [42], salt [36,37], eggs [35], and baby food [31] (Table 2). Anthropometric research parameters were body weight [43], birth weight [39], body weight based on age [31], body weight based on body length [31,38], height or length based on body weight $[31,41,44]$, and knee height. The biochemical nutritional status measurements included albumin level [43], serum retinol [32-34,38,39], hemoglobin [30,32,34,38,39,41], hematocrit [41], serum ferritin [30,39], and urine iodine excretion (UIE) [35-37]. The duration of the interventions or the length of the studies varied from 10 days to 1 year.

As seen in Table 2, iron fortification in candies at a dose of $30 \mathrm{mg}$ per week for 3 weeks increases hemoglobin and serum ferritin levels in children aged 4-6 years old [30]. The assessment of vitamin A fortified cooking oil in two provinces found different results. Studies have reported a significant increase in serum retinol levels, especially in the groups of toddlers and children aged 6-59 months and 5-9 years, respectively, in West Java after fortification [30,40]. In a study conducted in Makassar City, no difference in serum retinol level was found between groups with and without the consumption of Vitamin Afortified cooking oil [32]. Fortification of iodine in eggs for 10 days significantly increased the median UIE in children aged 10-12 years with iodine deficiency [35], whereas the fortification of iodine in salt for 6 months increased the median UIE but not significantly in children aged 6-12 years in Central Java [36]. A quasi-experimental study in Central Java showed a decrease in UIE after 6 months of fortification of iodine in salt in children aged 4-9 years [37].

Multinutrient fortification interventions were associated with varied results on nutritional status. Vitamin A and iron-fortified biscuit consumption increased the hemoglobin and serum retinol levels in children under 5 years old in a study conducted in Bogor Regency [38]; however, a study conducted in Semarang showed that iron and zinc fortification in tempeh rice-bran biscuits were associated with increased albumin levels and body weight, that were not significantly different from those of the control group [43]. A study conducted in Bogor District on pregnant women showed that the fortification of multinutrients in biscuits, vermicelli, and milk increased the hemoglobin levels but not the mothers' serum ferritin levels [39]. In addition, there was no significant association found between the hemoglobin levels and fortified food in the babies born to mothers with and without fortified food [41].

Regarding linear growth, a study reported that iron fortification in foods in a 9-month-old baby for 84 days ( 3 months) were associated with increased height for age at 12 months [31]. Among 6-month-old infants, the body lengths and body length gains were significantly higher in the group whose mothers were given multiple-nutrients-fortified foods compared to those in the control group [40]. Studies on children under 5 years old consuming fortified foods showed that foods fortified with multinutrients can increase the body length for age to prevent stunting $[31,44]$ (Table 3$)$. 
Table 3. Fortification outcome in several studies.

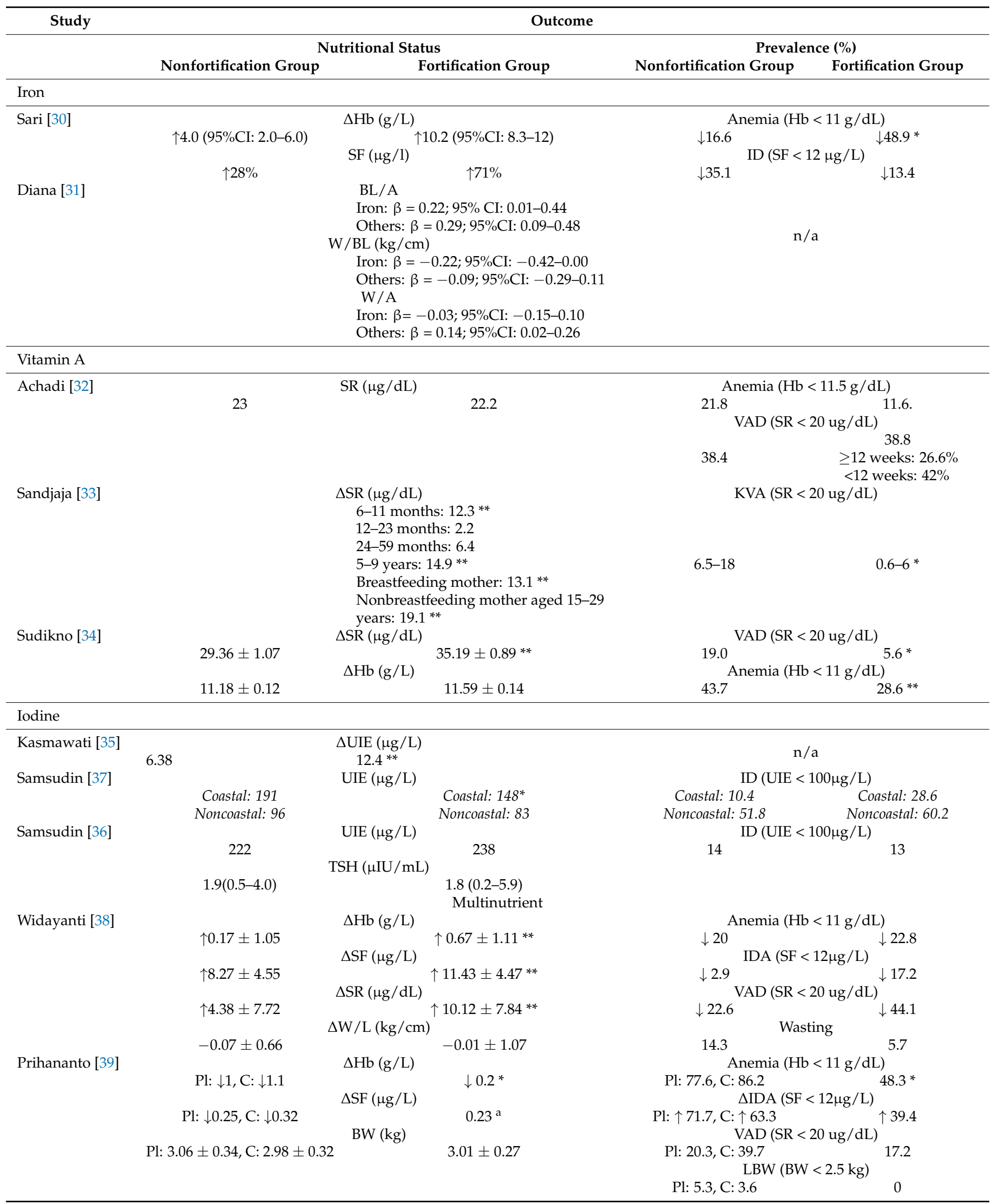


Table 3. Cont.

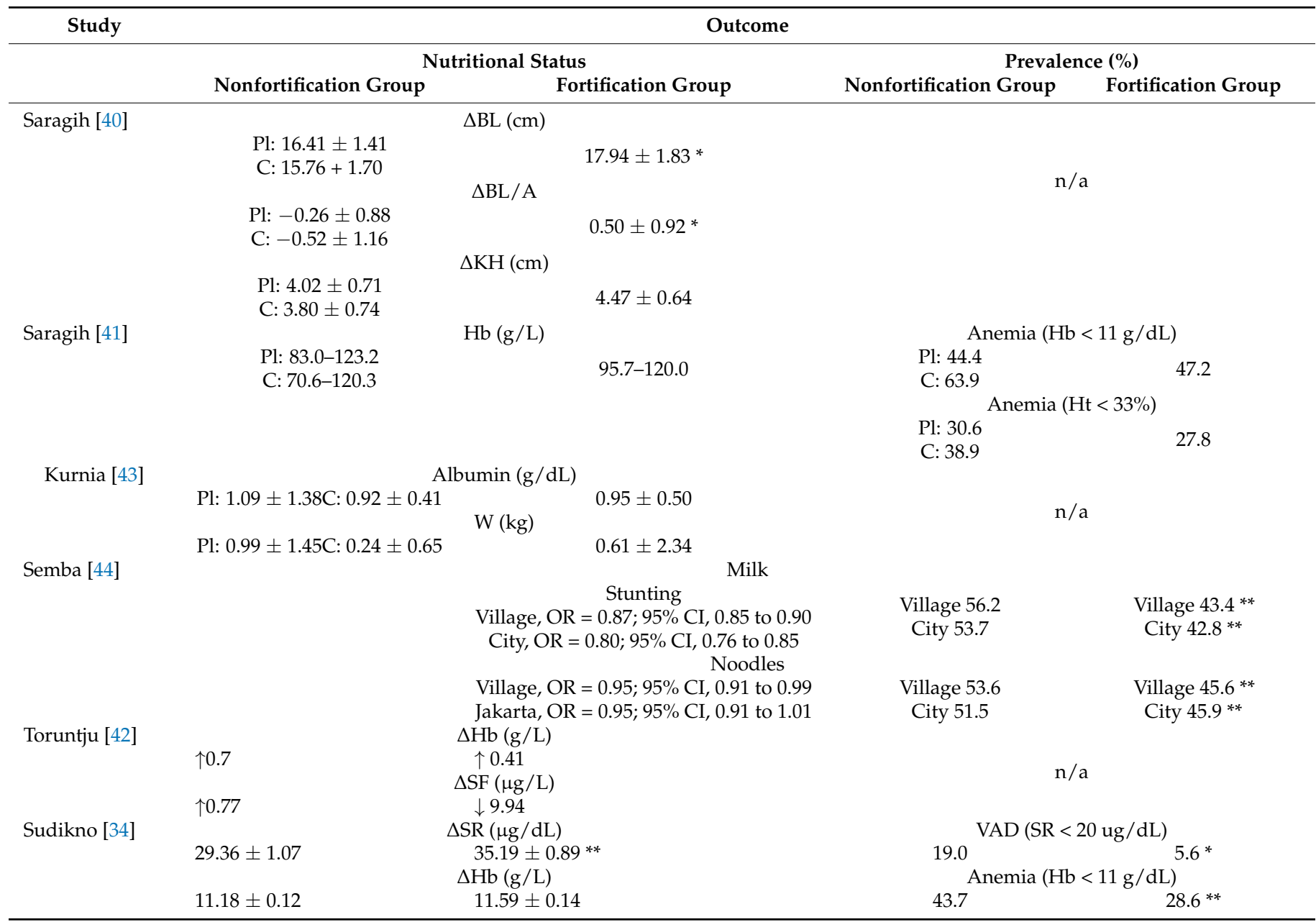

${ }^{*} p<0.05$ between the fortification and nonfortification group, ${ }^{* *} p<0.001$ between fortification and nonfortification group. ${ }^{\mathrm{a}} p<0.05$ between fortification and placebo. IDA, iron deficiency anemia; ID, iodine deficiency; BW, birth weight; BL, body length; LBW, low birth weight; BL/A, body length for age; W/BL, weight for body length; W/A, weight for age; HB, hemoglobin; SR, serum retinol; SF, serum ferritin; UIE, urine iodine excretion; $\mathrm{Ht}$, hematocrit; $\mathrm{KH}$, knee height; $\mathrm{Pl}$, placebo group; $\mathrm{C}$, control group.

\section{Discussion}

This review involved 15 studies conducted in the past 20 years. Most studies were conducted in Java Island, especially in the West Java region. West Java Province is the region with the largest population in Indonesia [45]. The longest study duration was 1 year. The average sample size of the studies reviewed was 100-200 individuals, with the largest study sample of 302,190 individuals in one study [44]; therefore, the large number of samples in this study could affect the power of the study [45]. Most studies assessed the effectiveness of multinutrient fortification using dairy as the most widely used food vehicle. The most widely performed biochemical parameters were hemoglobin and serum retinol, whereas the main anthropometric measure was height or body length for age.

Our review revealed that food fortification is effective in increasing hemoglobin and serum ferritin levels and decreasing the prevalence of anemia in infants, children, and toddlers $[20,46]$. In pregnant women, iron fortification could reduce the risk of preterm birth and giving birth to babies with low birth weight [21]. An RCT in Jakarta revealed that iron fortification in foodstuffs can increase the hemoglobin and serum ferritin levels of children aged 4-6 years with a weekly dose of $30 \mathrm{mg}$ of iron for 3 weeks [30]. However, studies in West Java showed that fortified rice with an iron dose of $>50 \mathrm{mg} / \mathrm{kg}$ could not increase the hemoglobin and serum ferritin levels in schoolchildren aged 12-15 years [42]. The results of RCTs are often different from those of effectiveness studies. Thus, these results 
need to be interpreted carefully, especially in evaluating the success of iron fortification of food, which is practiced in large scale. In Indonesia, iron fortification of wheat flour became mandatory starting in 2001, whereas iron-fortified rice began to be promoted by BULOG in 2019 [18]. The required dosage of flour fortification according to the Presidential Regulation of the Republic of Indonesia is at least $50 \mathrm{mg} / \mathrm{kg}$ of iron along with a minimum of $30 \mathrm{mg} / \mathrm{kg}$ of zinc, $2.5 \mathrm{mg} / \mathrm{kg}$ of thiamine, $4 \mathrm{mg} / \mathrm{kg}$ of riboflavin, and $2 \mathrm{mg} / \mathrm{kg}$ of folic acid [47].

Regarding anthropometric outputs, iron deficiency is closely related to the incidence of stunting. Iron functions in skeletal growth through the formation of collagen and metabolism of vitamin $\mathrm{D}$ which is required in bone formulations [48,49]. Iron deficiency impacts bone homeostasis through disruption of osteoclast and osteoblast activity and differentiation [50]. One study showed that iron fortification of infant foods could increase the body length based on the age of 12-month-old infants [31]. Studies conducted in other countries have revealed that iron fortification may improve iron status in the body but not body length for age [51-53] and may increase height for age but not significantly [54]. The effect of fortification was greater in subjects with anemia at baseline than that in those with normal condition [55].

Another form of food fortification found in Indonesia based on the results of our review was a nutrient improvement in cooking oil through vitamin A fortification. The effectiveness of vitamin A fortification in improving vitamin A status in Indonesia was evaluated in two studies. An evaluation study of the use of fortified cooking oil in Makassar City, South Sulawesi, for 3 months did not show changes in serum retinol in the intervention group [32]. However, this study showed that the prevalence (26.6\%) of vitamin A deficiency was lower in children who consumed fortified oil for $\geq 12$ weeks compared to children who consumed fortified oil for less than 12 weeks (42\%) [32]. A study involving infants, girls, and breastfeeding mothers in West Java for 1 year at a dose of $13.6 \mathrm{mg}$ retinol $/ \mathrm{kg}$ of food vehicle showed that vitamin A-fortified cooking oil significantly increased serum retinol [33]. The longer duration of fortified oil consumption affects the storage of vitamin A in the body, thus increasing vitamin A status [56]. Positive results have been also found in several countries regarding the effects of fortification of food with vitamin A in increasing serum retinol levels [26].

Another nutrient that was widely used in food fortification was Iodine. Iodine fortification in Indonesia began during the Dutch occupation era in 1927, stopped in 1945, and restarted in 1976 [57]. Moreover, the Urine Iodine Excretion (UIE) of schoolchildren increased from $164.8 \mu \mathrm{g} / \mathrm{L}$ in 1995 to $330.2 \mu \mathrm{g} / \mathrm{L}$ in 1997 and $306.0 \mu \mathrm{g} / \mathrm{L}$ in 1999 [57]. The schoolchildren in only one province showed UIE of $<100 \mu \mathrm{g} / \mathrm{L}$ in 1999 [57]. A quasiexperimental study in Central Java in 2015 was not associated with an increase in median UIE or a decrease in the prevalence of iodine deficiency of $<100 \mu \mathrm{g} / \mathrm{L}$ UIE in children aged 4-9 years [37]. RCTs in different parts of central Java using fortified iodine doses of $15-55 \mathrm{mg} / \mathrm{kg}$ increased the UIE in children 6-12 years, but this did not reach statistical significance [36]. One study in South Sulawesi showed that the fortification of eggs with iodine for 10 days at a fortification dose of $0.4 \mathrm{mg} / \mathrm{kg}$ significantly increased the median UIE in children aged 10-12 years [35]. Quasi-experimental studies and RCTs conducted in Central Java found that the consumption habits of iodine sources were significantly different between groups [36,37], thus potentially affecting the results obtained.

The multi-micronutrient interventions in this review showed various results in improving the biochemical nutritional status in mothers and children. Vitamin A- and ironfortified biscuits could increase the hemoglobin and serum retinol levels in toddlers [38], whereas the fortification of biscuits, vermicelli, and milk with multinutrients could increase the hemoglobin but not serum ferritin levels of mothers and showed no effect on the hemoglobin levels of babies $[39,40]$. In pregnant women, the phenomenon of decreasing serum ferritin may occur due to the use of ferritin in increasing the mass of maternal blood cells [58]. In studies conducted in various countries, the provision of multinutrient-fortified foods has a positive effect on reducing the prevalence of anemia and iron deficiency in 
mothers [59]. Two studies indicated that multinutrient fortification interventions had a significant positive influence on the body length growth and the $\mathrm{z}$ score for body length based on infant age [31,40]. In addition, a study showed that multinutrient fortification interventions reduced the prevalence of stunting in toddlers [44]. The effectiveness of multinutrient fortification on improving the linear growth in Indonesia can be explained by the pre-existing multinutrient deficiencies that may be experienced by individuals in the population [60]. Since macronutrient deficiencies such as wasting and underweight remain a major public health problem in Indonesia [2], protein and energy malnutrition likely affect the body's physiological functions [61]. Lack of these nutrients causes rapid growth failure because micronutrients cannot be of maximum benefit according to their function in linear growth [61,62].

Multinutrient fortification had a positive impact on the linear growth although the impact is still insignificant in children [63,64]. Nevertheless, the statistically insignificant result does not mean that the change was not biologically significant to the health of the individuals, particularly with respect to children. The difference in results from those found in Indonesia could be due to differences in the duration of the intervention performed [54,55], the type of vehicle used [51,54], the target group in the study [54], or pre-existing micronutrient deficiency conditions that were unknown at the start of the study [55].

Although food fortification in Indonesia showed promising results in improving nutritional status and decreasing the prevalence of anemia, iron deficiency, and vitamin A deficiency, various studies with longer durations of body height escalation assessment involving large study samples are needed to discover the effectiveness of food fortification on body height escalation and the reduction of stunting prevalence. In addition, this study did not evaluate the types of fortification methods used due to the lack of information available from the studies reviewed. To the best of our knowledge, this study is the first systematic review describing the effectiveness of nutrient fortification in food in improving the nutritional status in children and pregnant women in Indonesia.

\section{Conclusions}

The effectiveness of food fortification in reducing micronutrient deficiency problems in Indonesia presents promising results; however, the effectiveness of food fortification in reducing the prevalence of stunting still needs more and stronger evidence, although several studies have indicated positive results. Nonetheless, this review might be a starting point for a sound strategy for future studies pertaining to the level and duration of food fortificant used.

Author Contributions: Conceptualization, N.U.D.; methodology, N.U.D. and T.M.; software, N.U.D.; validation, N.U.D.; formal analysis, N.U.D.; investigation, N.U.D. and T.M.; resources, N.U.D.; data curation, T.M.; writing: original draft preparation, N.U.D.; writing: review and editing, T.M.; visualization, N.U.D.; supervision, T.M.; project administration, N.U.D.; funding acquisition, N.U.D. and T.M. All authors have read and agreed to the published version of the manuscript.

Funding: This research received no external funding.

Institutional Review Board Statement: Institutional Review Board KEPK Faculty of Public Health University of Airlangga exempted this study since it was systematic review derived from secondary evidence.

Informed Consent Statement: Informed consent from participant is not applicable for this review.

Data Availability Statement: Availability of the data will be release upon request through corresponding authors.

Conflicts of Interest: The authors declare no conflict of interest. 


\section{References}

1. Ruel-Bergeron, J.C.; Stevens, G.A.; Sugimoto, J.D.; Roos, F.F.; Ezzati, M.; Black, R.E.; Kraemer, K. Global Update and Trends of Hidden Hunger, 1995-2011: The Hidden Hunger Index. PLoS ONE 2015, 10, e0143497. [CrossRef]

2. Balitbangkes. Riset Kesehatan Dasar; Badan Penelitian dan Pengembangan Kesehatan Kementerian Kesehatan Republik Indonesia: Jakarta, Indonesia, 2018.

3. Balitbangkes. Riset Kesehatan Dasar; Badan Penelitian dan Pengembangan Kesehatan Kementerian Kesehatan Republik Indonesia: Jakarta, Indonesia, 2013.

4. Desmansyah, D.; Purnamasari, R.; Theodorus, T.; Waiman, S. Correlation between vivax malaria infection and iron deficiency in children. Paediatr. Indones. 2011, 51, 207-212. [CrossRef]

5. Zahrulianingdyah, A. The contribution of Indonesian women's eating habit to iron deficiency anemia. Pakistan J. Nutr. 2016, 15, 1003-1007. [CrossRef]

6. Nurdia, D.S.; Sumarni, S.; Suyoko; Hakim, M.; Winkvist, A. Impact of intestinal helminth infection on anemia and iron status during pregnancy: A community based study in Indonesia. S. Asian J. Trop. Med. Public Health 2001, 32, 14-22.

7. Andriastuti, M.; Ilmana, G.; Nawangwulan, S.A.; Kosasih, K.A. Prevalence of anemia and iron profile among children and adolescent with low socio-economic status. Int. J. Pediatr. Adolesc. Med. 2019. [CrossRef]

8. Bening, S.; Margawati, A.; Rosidi, A. Zinc deficiency as risk factor for stunting among children aged 2-5 years. Universa Med. 2017, 36, 11-18. [CrossRef]

9. Abdelhaleim, A.F.; Abdo Soliman, J.S.; Amer, A.Y.; Abdo Soliman, J.S. Association of Zinc Deficiency with Iron Deficiency Anemia and its Symptoms: Results from a Case-control Study. Cureus 2019, 11, e3811. [CrossRef]

10. WHO. WHO Nutrition Landacape Information System (NLIS) Country Profile Indicators, Interpretation Guide; WHO: Geneva, Switzerland, 2010.

11. Kementerian PPN/Bapennas. Rencana Pembangunan Jangka Menengah Nasional 2020-2024; Kementerian PPN/Bapennas: Jakarta, Indonesia, 2019.

12. Arnold, T. Chapter 5.4 Nutrition-Specific and Nutrition-Sensitive Interventions. In Good Nutrition: Perspectives for the 21st Century; Karger: Basel, 2016; pp. 276-288.

13. WHO. WHO and FAO Guidelines on Food Fortification with Micronutrients; WHO: Geneva, Switzerland, 2006.

14. Pilz, S.; März, W.; Cashman, K.D.; Kiely, M.E.; Whiting, S.J.; Holick, M.F.; Grant, W.B.; Pludowski, P.; Hiligsmann, M.; Trummer, C.; et al. Rationale and Plan for Vitamin D Food Fortification: A Review and Guidance Paper. Front. Endocrinol. (Lausanne) 2018, 9, 373. [CrossRef] [PubMed]

15. Haas, J.D.; Luna, S.V.; Lung'aho, M.G.; Wenger, M.J.; Murray-Kolb, L.E.; Beebe, S.; Gahutu, J.-B.; Egli, I.M. Consuming Iron Biofortified Beans Increases Iron Status in Rwandan Women after 128 Days in a Randomized Controlled Feeding Trial. J. Nutr. 2016, 146, 1586-1592. [CrossRef]

16. Finkelstein, J.L.; Fothergill, A.; Hackl, L.S.; Haas, J.D.; Mehta, S. Iron biofortification interventions to improve iron status and functional outcomes. Proc. Nutr. Soc. 2019, 78, 197-207. [CrossRef]

17. Menteri Perindustrian. Peraturan Menteri Perindustrian Republik Indonesia Nomor 47 tahun 2018 tentang Perubahan Ketiga atas Peraturan Menteri Perindustrian Nomor 87/M-IND/PER/12/2013 tentang Pemberlakuan SNI Minyak Goreng Sawit Secara Wajib; Menteri Perindustrian Republik Indonesia: Jakarta, Indonesia, 2018.

18. Minister of Industry. Minister of Industry and Trade Regulation Number 153/MPP/Kep/5/2001; Minister of Industry and Trade Republic of Indonesia: Jakarta, Indonesia, 2001.

19. Presiden Republik Indonesia. Keputusan Presiden Republik Indonesia Nomor 69 Tahun 1994 tentang Pengadaan Garam Beriodium; Presiden Republik Indonesia: Jakarta, Indonesia, 1994.

20. Sadighi, J.; Nedjat, S.; Rostami, R. Systematic review and meta-analysis of the effect of iron-fortified flour on iron status of populations worldwide. Public Health Nutr. 2019, 22, 3465-3484. [CrossRef]

21. Athe, R.; Dwivedi, R.; Pati, S.; Mazumder, A.; Banset, U. Meta-analysis approach on iron fortification and its effect on pregnancy and its outcome through randomized, controlled trials. J. Fam. Med. Prim. Care 2020, 9, 513.

22. Tam, E.; Keats, E.C.; Rind, F.; Das, J.K.; Bhutta, Z.A. Micronutrient Supplementation and Fortification Interventions on Health and Development Outcomes among Children Under-Five in Low- and Middle-Income Countries: A Systematic Review and Meta-Analysis. Nutrients 2020, 12, 289. [CrossRef]

23. Pineda, O. Fortification of sugar with vitamin A. Food Nutr. Bull. 1998, 19, 131-136. [CrossRef]

24. Favaro, R.M.D.; Miyasaaka, C.K.; Desai, I.D.; Dutra de Oliveira, J.E. Evaluation of the effect of heat treatment on the biological value of vitamin A fortified soybean oil. Nutr. Res. 1992, 12, 1357-1363. [CrossRef]

25. Mendu, V.V.R.; Nair, K.P.M.; Athe, R. Systematic review and meta-analysis approach on vitamin A fortified foods and its effect on retinol concentration in under 10 year children. Clin. Nutr. ESPEN 2019, 30, 126-130. [CrossRef] [PubMed]

26. Hombali, A.S.; Solon, J.A.; Venkatesh, B.T.; Nair, N.S.; Peña-Rosas, J.P. Fortification of staple foods with vitamin A for vitamin A deficiency. Cochrane Database Syst. Rev. 2019. [CrossRef] [PubMed]

27. Santos, J.A.R.; Christoforou, A.; Trieu, K.; McKenzie, B.L.; Downs, S.; Billot, L.; Webster, J.; Li, M. Iodine fortification of foods and condiments, other than salt, for preventing iodine deficiency disorders. Cochrane Database Syst. Rev. 2019, 2019. [CrossRef] [PubMed] 
28. Aburto, N.J.; Abudou, M.; Candeias, V.; Tiaxiang Wu, P. Effect and safety of salt iodization to prevent iodine deficiency disorders: A systematic review with meta-analyses WHO Library Cataloguing-in-Publication Data. In WHO eLibrary of Evidence for Nutrition Actions (eLENA); WHO: Geneva, Switzerland, 2014; pp. 91-93.

29. Dijkhuizen, M.A.; Wieringa, F.T.; Soekarjo, D.; Van, K.T.; Laillou, A. Legal Framework for Food Fortification: Examples from Vietnam and Indonesia. Food Nutr. Bull. 2013, 34, S112-S123. [CrossRef]

30. Sari, M.; Bloem, M.W.; de Pee, S.; Schultink, W.J.; Sastroamidjojo, S. Effect of iron-fortified candies on the iron status of children aged 4-6 y in East Jakarta, Indonesia. Am. J. Clin. Nutr. 2001, 73, 1034-1039. [CrossRef] [PubMed]

31. Diana, A.; Mallard, S.R.; Haszard, J.J.; Purnamasari, D.M.; Nurulazmi, I.; Herliani, P.D.; Nugraha, G.I.; Gibson, R.S.; Houghton, L. Consumption of fortified infant foods reduces dietary diversity but has a positive effect on subsequent growth in infants from Sumedang district, Indonesia. PLoS ONE 2017, 12, e0175952. [CrossRef]

32. Achadi, E.; Arifah, S.; Muslimatun, S.; Anggondowati, T.; Setiarini, A. Efektivitas Program Fortifikasi Minyak Goreng dengan Vitamin A terhadap Status Gizi Anak Sekolah di Kota Makasar. Kesmas Natl. Public Health J. 2010, 4, 255. [CrossRef]

33. Sandjaja; Jusat, I.; Jahari, A.B.; Ifrad; Htet, M.K.; Tilden, R.L.; Soekarjo, D.; Utomo, B.; Moench-Pfanner, R.; Soekirman; et al. Vitamin A-fortified cooking oil reduces Vitamin A deficiency in infants, young children and women: Results from a programme evaluation in Indonesia. Public Health Nutr. 2015, 18, 2511-2522. [CrossRef] [PubMed]

34. Sudikno, S.; Jus, I. The Impact of Vitamin A Fortified Vegetable Oil on Vitamin A Status of Children Under Five Years of Age: A Cohort Study. Health Sci. J. Indones. 2017, 8, 102-110. [CrossRef]

35. Kasmawati. Pengaruh Pemberian Telur Beriodium terhadap Ekskresi Iodium Urin Penderita Defisiensi Yodium pada Anak Sekolah Dasar Kecamatan Pondidaha Kabupaten Konawe; Universitas Hasanuddin: Makassar, Indonesia, 2015.

36. Samsudin, M.; Nurcahyani, Y.D.; Ihsan, N.; Litbang, B.; Magelang, G.; Jayan, K. Dampak Intervensi Garam Beriodium Berbagai Dosis Terhadap Status Iodium Dan Fungsi Tiroid Normal Pada Anak Sekolah Dasar. Media Gizi Mikro Indones. 2016, 8, 1-16.

37. Samsudin, M.; Kusumawardani, H.; Prihatmi, E. Pengaruh penggunaan garam beriodium standar terhadap status iodium tinggi di daerah non endemik. Media Gizi Mikro Indones. 2015, 7, 57-66.

38. Widayani, S. Efikasi Dan Preferensi Biskuit Yang Difortifikasi Vitamin A Dan Zat Besi (Fe) Dan Kaitannya Dengan Konsumsi, Status Gizi dan Respon Imun Anak Balita; IPB University: Bogor, Indonesia, 2007.

39. Prihananto, V. Pengaruh Pemberian Pangan Yang Difortifikasi Zat Multi Gizi Mikro Terhadap Status Gizi Ibu Hamil Dan Berat Bayi Lahir; Dissertation; IPB University: Bogor, Indonesia, 2007.

40. Saragih, B.; Syarief, H.; Riyadi, H.; Nasoetion, A. Pengaruh Pemberian Pangan Fortifikasi Zat Multi Gizi Mikro Pada Ibu Hamil Terhadap Pertumbuhan Linier, Tinggi Lutut Dan Status Anemia Bayi. Gizi Indones. 2007, 30. [CrossRef]

41. Saragih, B.; Syarief, H.; Riyadi, H.; Nasoetion, A. Pangan yang difortifikasi zat gizi mikro pada ibu hamil meningkatkan perkembangan motorik bayi. J. Gizi Klin. Indones. 2012, 9, 16. [CrossRef]

42. Toronju, S.A.; Syam, A.; Palutturi, S.; Arif, M. Study of Hemoglobin and Ferritin Profile as Indicators in Children Hematology of 12-15 Years Provided Local Rice Fortification. Int. J. Sci. Basic Appl. Res. 2017, 32, 352-364.

43. Kurnia, P.; Rahmawaty, S. Efek Fortifikasi Fe dan Zn pada biskuit yang diolah dari kombinasi Tempe dan Bekatul untuk meningkatkan kadar Albumin Anak Balita Kurang Gizi dan Anemia. Eksplanasi 2010, 5, 1-14.

44. Semba, R.D.; Moench-Pfanner, R.; Sun, K.; De Pee, S.; Akhter, N.; Rah, J.H.; Campbell, A.A.; Badham, J.; Bloem, M.W.; Kraemer, K. Consumption of micronutrient-fortified milk and noodles is associated with lower risk of stunting in preschool-aged children in Indonesia. Food Nutr. Bull. 2011, 32, 347-353. [CrossRef]

45. BPS-Statistics Indonesia. Statistical Yearbook of Indonesia; BPS-Statistics Indonesia: Jakarta, Indonesia, 2019.

46. Gera, T.; Sachdev, H.S.; Boy, E. Effect of iron-fortified foods on hematologic and biological outcomes: Systematic review of randomized controlled trials. Am. J. Clin. Nutr. 2012, 96, 309-324. [CrossRef] [PubMed]

47. Minister of Health. Minister of Health Regulation No. 1452/MENKES/SK/X/2003; Minister of Health: Jakarta, Indonesia, 2003.

48. Zofkova, I.; Davis, M.; Blahos, J. Trace elements have beneficial, as well as detrimental effects on bone homeostasis. Physiol. Res. 2017, 66, 391-402. [CrossRef]

49. Toxqui, L.; Vaquero, M.P. Chronic iron deficiency as an emerging risk factor for osteoporosis: A hypothesis. Nutrients 2015, 7, 2324-2344. [CrossRef] [PubMed]

50. Balogh, E.; Paragh, G.; Jeney, V. Influence of Iron on Bone Homeostasis. Pharmaceuticals 2018, 11, 107. [CrossRef] [PubMed]

51. Owino, V.O.; Kasonka, L.M.; Sinkala, M.M.; Wells, J.K.; Eaton, S.; Darch, T.; Coward, A.; Tomkins, A.M.; Filteau, S.M. Fortified complementary foods with or without $\alpha$-amylase treatment increase hemoglobin but do not reduce breast milk intake of 9-mo-old Zambian infants. Am. J. Clin. Nutr. 2007, 86, 1094-1103. [CrossRef] [PubMed]

52. Ara, G.; Khanam, M.; Rahman, A.S.; Islam, Z.; Farhad, S.; Sanin, K.I.; Khan, S.S.; Rahman, M.M.; Majoor, H.; Ahmed, T. Effectiveness of micronutrient-fortified rice consumption on anaemia and zinc status among vulnerable women in Bangladesh. PLoS ONE 2019, 14, e0210501. [CrossRef]

53. Angeles-agdeppa, I.; Capanzana, M.V.; Barba, C.V.C.; Florentino, R.F.; Takanashi, K. Efficacy of Iron-Fortified Rice in Reducing Anemia Among Schoolchildren in the Philippines. Int. J. Vitam. Nutr. Res. 2008, 78, 74-86. [CrossRef] [PubMed]

54. Chen, J.; Zhao, X.; Zhang, X.; Yin, S.; Piao, J.; Huo, J.; Yu, B.; Qu, N.; Lu, Q.; Wang, S.; et al. Studies on the Effectiveness of Nafeedta-Fortified Soy Sauce in Controlling Iron Deficiency: A Population-Based Intervention Trial. Food Nutr. Bull. 2005, 26, 177-186. [CrossRef] [PubMed] 
55. Waller, A.W.; Andrade, J.E.; Mejia, L.A. Performance Factors Influencing Efficacy and Effectiveness of Iron Fortification Programs of Condiments for Improving Anemia Prevalence and Iron Status in Populations: A Systematic Review. Nutrients 2020, 12, 275. [CrossRef] [PubMed]

56. Green, A.S.; Fascetti, A.J. Meeting the Vitamin A Requirement: The Efficacy and Importance of $\beta$-Carotene in Animal Species. Sci. World J. 2016, 2016, 7393620. [CrossRef] [PubMed]

57. Zhang, X.; Chen, K.; Qu, P.; Liu, Y.-X.; Li, T.-Y. Effect of biscuits fortified with different doses of vitamin A on indices of vitamin A status, haemoglobin and physical growth levels of pre-school children in Chongqing. Public Health Nutr. 2010, 13, 1462-1471. [CrossRef] [PubMed]

58. Allen, L.H. Anemia and iron deficiency: Effects on pregnancy outcome. Am. J. Clin. Nutr. 2000, 71, 1280S-1284S. [CrossRef] [PubMed]

59. Yang, Z.; Huffman, S.L. Review of fortified food and beverage products for pregnant and lactating women and their impact on nutritional status. Matern. Child Nutr. 2011, 7, 19-43. [CrossRef] [PubMed]

60. Darnton-Hill, I.; Mkparu, U.C. Micronutrients in Pregnancy in Low- and Middle-Income Countries. Nutrients 2015, 7, 1744-1768. [CrossRef]

61. Branca, F.; Ferrari, M. Impact of Micronutrient Deficiencies on Growth: The Stunting Syndrome. Ann. Nutr. Metab. 2002, 46 (Suppl. 1), 8-17. [CrossRef]

62. Habicht, J.-P.; Martorell, R.; Rivera, J.A. Nutritional Impact of Supplementation in the INCAP Longitudinal Study: Analytic Strategies and Inferences. J. Nutr. 1995, 125, 1042S-1050S.

63. Okeyo, D.O. Impact of Food Fortification on Child Growth and Development during Complementary Feeding. Ann. Nutr. Metab. 2018, 73, 7-13. [CrossRef] [PubMed]

64. Das, J.K.; Salam, R.A.; Kumar, R.; Bhutta, Z.A. Micronutrient fortification of food and its impact on woman and child health: A systematic review. Syst. Rev. 2013, 2, 67. [CrossRef] 